\title{
Characterization of surface topography and chemical composition of mini-implants
}

\author{
Luegya Amorim Henriques Knop ${ }^{1}$, Ana Prates Soares ${ }^{2}$, Ricardo Lima Shintcovsk ${ }^{1}$, \\ Lidia Parsekian Martins ${ }^{1}$, Luiz Gonzaga Gandini Jr. ${ }^{1}$
}

\author{
${ }^{1}$ Universidade Estadual Paulista - UNESP, Araraquara Dental School, Department of Orthodontics and Pediatric Clinic, Araraquara, São Paulo, Brazil \\ ${ }^{2}$ Universidade de São Paulo - USP, Hospital of Rehabilitation of Oralfacial Anomalies, Area of Prosthodontics, Bauru, São Paulo, Brazil
}

\begin{abstract}
Aim: To assess the surface topography and chemical composition of three brands of as-received mini-implants (SIN ${ }^{\circledast}$, Morelli ${ }^{\circledR}$, and Conexao ${ }^{\circledR}$ ). Methods: Twelve mini-implants of each brand were analyzed by scanning electron microscopy and energy dispersive X-ray (EDX). Results: There was no significant differences among $\mathrm{SIN}^{\circledR}$, Morelli ${ }^{\circledR}$, and Conexa $0^{\circledR}$ mini-implants comparing their surface topography by visualization of SEM micrographs and analysis of scores. The EDX analysis showed statistically significant difference among them for the amount of $\mathrm{Ti}, \mathrm{Al}$ and $\mathrm{V}$. Miniimplants SIN ${ }^{\otimes}$ presented also $\mathrm{N}$ and $\mathrm{O}$ in their composition. Conclusions: In conclusion, the miniimplants Morelli®, SIN ${ }^{\circledR}$ and Conexao ${ }^{\circledR}$ presented Ti as main component of the alloy. Remaining components, such as Al and $\mathrm{V}$, were also observed in all the analyzed brands, with differences among them. Only $\operatorname{SIN}^{\circledR}$ mini-implants presented $\mathrm{N}$ and $\mathrm{O}$. As far as surface topography is concerned, there are no differences among the three brands of mini-implants.
\end{abstract}

Keywords: orthodontics; orthodontic anchorage procedures; titanium.

\section{Introduction}

Temporary anchorage devices (TADs) such as mini-implants act as skeletal anchorage for Orthodontic movements. TADs are used when dental anchorage is insufficient or a large amount of dental movement is required ${ }^{1}$. These devices are widely used in Orthodontics offering excellent results and solving anchorage problems that could not be addressed previously ${ }^{2}$ by overcoming the active versus reactive forces generated during tooth movement ${ }^{3}$.

The optimal use of TAD should have some requirements such as small size, placement without drilling, stability to withstand immediate and long term loading, easy removal and comfort for the patient ${ }^{4}$. All these features, especially the small dimensions of mini-implants, require a strong, high-grade titanium alloy. Grade $5 \mathrm{Ti}$, also known as Ti-6Al-4V, is composed of $6 \%$ aluminum, $4 \%$ nittro, $0.25 \%$ (maximum) iron, $0.2 \%$ (maximum) oxygen and Ti (remaining

Received for publication: August 26, 2015 Accepted: September 30, 2015

Correspondence to: Luegya Amorim Henriques Knop Rua Magno Valente, 110, Apartmento 1401 A, Pituba CEP: 41810-620 Salvador, BA, Brasil Phone: +557133583338 E-mail: luegya@gmail.com percentage). The result is a combination of strength and fabricability ${ }^{5}$. In biological terms, grade 5 machined Ti promotes cell proliferation, good cytocompatibility and cell adhesion ${ }^{4}$ although it does not provide a good-quality osseointegration, which facilitates removal when needed ${ }^{6}$. The design of miniimplants should feature a head to engage elastic bands or sprains, a smooth transmucosal neck, an endossous self tapping body and a special groove in their tip to be used for cutting or tapping the bone during insertion, which is called lead angle ${ }^{1}$. 
Manufacturers can create mini-implants in different shapes and sizes. While they usually supply information on outer diameter and length, chemical composition, depth, pitch, lead angle of the thread as well as surface characteristics are rarely provided ${ }^{7-8}$. The objective of this study was to assess the surface topography and chemical composition of three brands of mini-implants (Morelli ${ }^{\circledR}, \mathrm{SIN}^{\circledR}$ and Conexao ${ }^{\circledR}$ ) by scanning electron microscopy (SEM) and energy dispersive X-ray (EDX).

\section{Material and methods}

The sample was composed of 36 mini-implants of 3 different commercial brands: SIN $^{\circledR}$ (São Paulo, SP, Brazil; $\mathrm{n}=12,1.4 \mathrm{~mm}$ diameter, $8 \mathrm{~mm}$ length), Morelli ${ }^{\circledR}$ (Sorocaba, SP, Brazil; $\mathrm{n}=12,1.5 \mathrm{~mm}$ diameter, $8 \mathrm{~mm}$ length), and Conexao $^{\circledR}$; (Aruja, SP, Brazil; $\mathrm{n}=12,1.5 \mathrm{~mm}$ diameter, 8 $\mathrm{mm}$ length). All mini-implants were individually packaged and used as received from the manufacturers. Packages were only opened at the beginning of each analysis and carefully handled in order to prevent contamination.

\section{Analysis of Surface Topography by SEM}

The specimens were fixed on SEM-stub-holders and visualized through a field- emission scanning electron microscope (FE-SEM) type 6301F (JEOL Ltd., Tokyo, Japan) at $2 \mathrm{kV}$ with a working distance of $39 \mathrm{~mm}$ and a small spot size. Representative SEM micrographs of the head, body and notch were taken from each sample of the different brands. A single experienced examiner viewed the samples at 30,60 and $75 \mathrm{x}$ magnification to obtain the images after brightness, contrast and focus adjustments. Surface texture was observed and described in a qualitative manner, comparing the groups.

Mini-implant topography was evaluated according to the following scoring system: (0) absence of defects and irregularities (like striations or protrusions); (1) presence of defects in up to $25 \%$ of the mini-implant threads; (2) presence of defects in up to $50 \%$ of the mini-implant threads; (3) presence of defects in up to $75 \%$ of the miniimplant threads; (4) presence of defects in all mini-implant threads. The mean scores were analyzed statically by ANOVA and Tukey's test. Significance level was t at $5 \%$.

\section{Analysis of Chemical Composition by EDX}

The chemical composition of the same all miniimplants was analyzed by EDX at the same sites of the topographical analysis. The EDX generated graphics composed of the chemical compounds found in the device and their respective amounts. The information was gathered in a single table, which was used for the statistical analysis. Data were analyzed by ANOVA followed by Tukey's posttest to detect differences regarding the amount of the studied chemical elements $(\mathrm{C}, \mathrm{Al}, \mathrm{Ti}$, and $\mathrm{V})$ in each mini-implant brand. Significance level was $t$ at $5 \%$.

\section{Results}

\section{Surface Topography}

$\mathrm{SIN}^{\circledR}$ mini-implants were characterized by a clearly wellpolished and visible head (Figure 1), uniform unidirectional threads, likely to be the result of machining. The machined metal surface of SIN ${ }^{\circledR}$ appeared to be more satisfactory defined with few structural defects among the 12 (Figure 2). Morelli ${ }^{\circledR}$ mini-implants revealed uniform threads, but with some surface defects, especially on the body. In addition, small irregularities, such as striations, were also visible on a typical machined metal surface (Figure 3). Conexao ${ }^{\circledR}$ mini-implants presented no equivalent distance among the threads, with larger distances among the threads on the body compared with the head. The surface was homogenous, well polished, and with few structural defects such as protrusion (Figure 4). On the notch we observed a vertical design that is possibly very relevant to bone drilling (Figure 5).

The three mini-implant groups received score 1 (mean), with no statistically significant difference among the brands $(p>0.05)$.

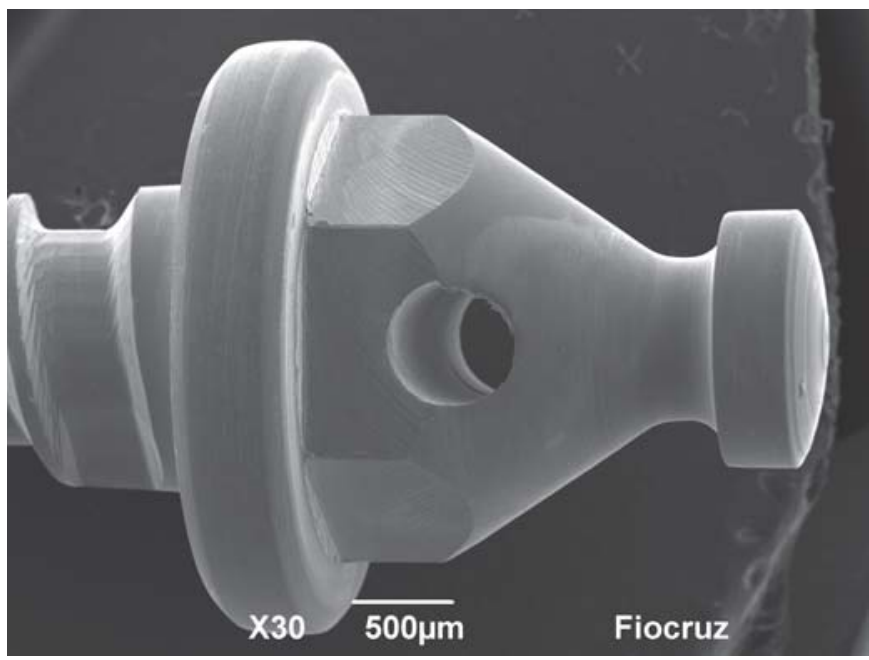

Fig. 1. SEM micrograph of the head of a $\operatorname{SIN}^{\circledR}$ mini-implant $(x 30)$

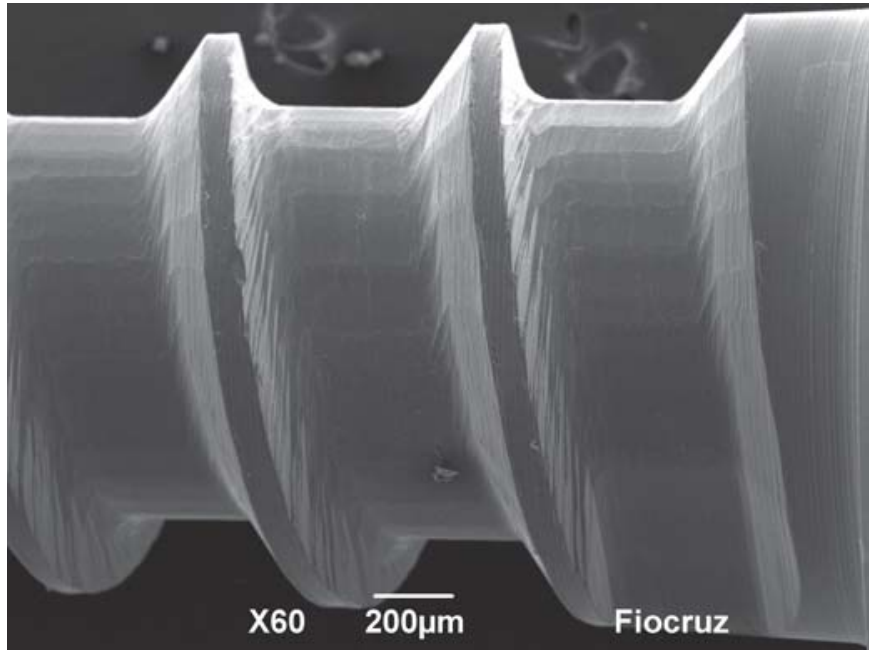

Fig. 2.SEM micrograph of the body of a $\operatorname{SIN}^{\circledR}$ mini-implant showing a small defect (x60) 


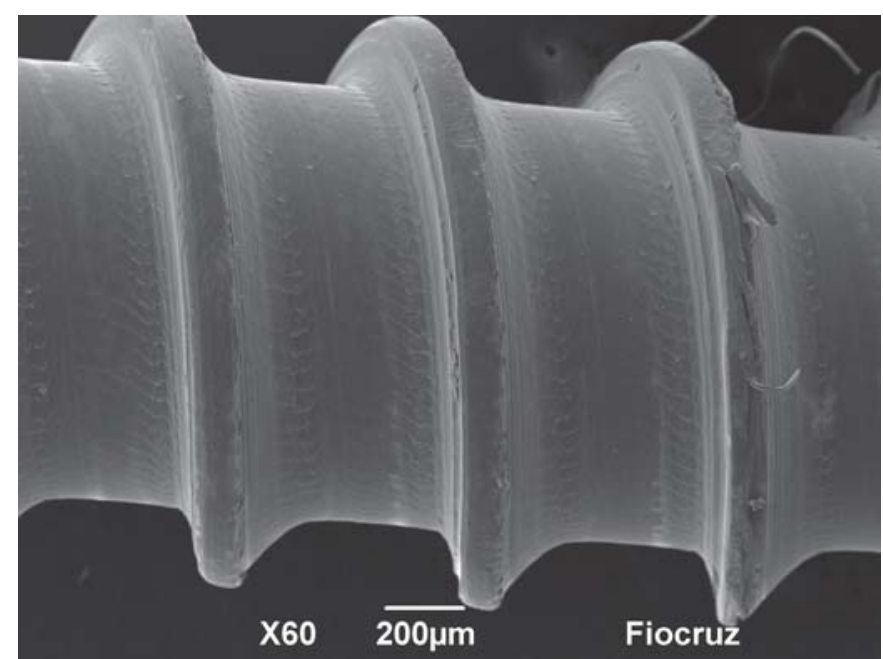

Fig. 3. SEM micrograph of the body of a Morelli ${ }^{\circledR}$ mini-implant showing evident surface roughness (x60)

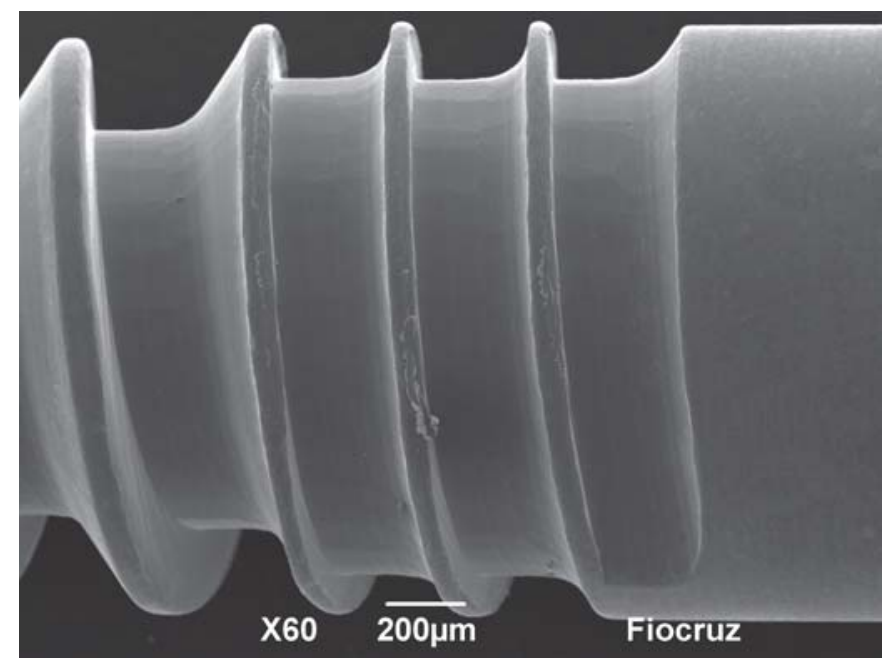

Fig. 4. SEM micrograph of the body of Conexao ${ }^{\circledR}$ mini-implant. A well-polished surface can be observed, with small defects (x60)

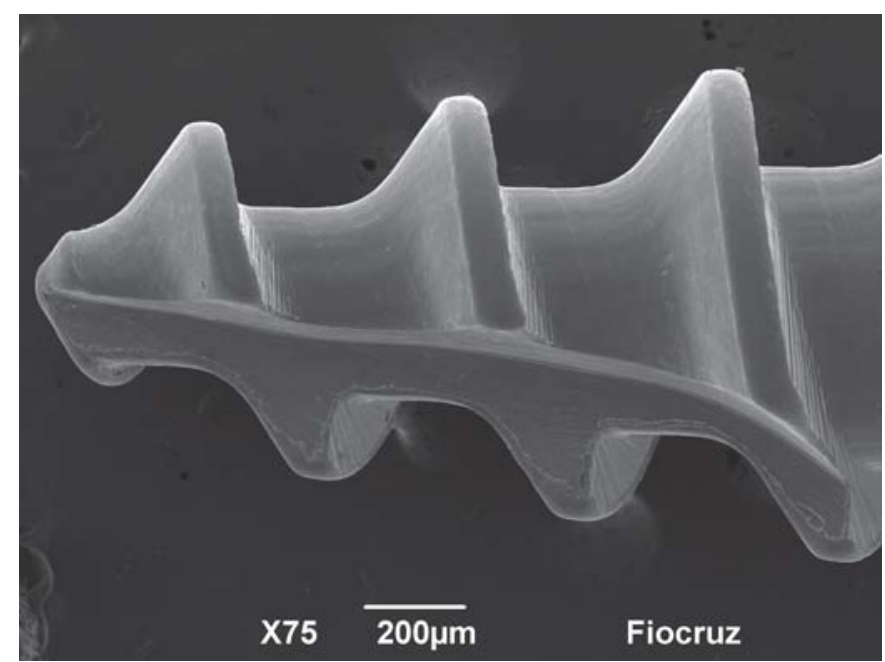

Fig. 5. SEM micrograph of the notch of Conexao ${ }^{\circledR}$ mini-implant $(x 75)$

\section{Chemical composition}

Mini-implants from SIN $^{\circledR}$, Morelli ${ }^{\circledR}$ and Conexao ${ }^{\circledR}$ had
$\mathrm{Ti}, \mathrm{O}, \mathrm{Al}$ and $\mathrm{V}$ in their composition. Carbon and nitrogen in smaller amounts were found as impurities in $\mathrm{SIN}^{\circledR}$ miniimplants (Figure 6). It was not possible to conduct statistical inference regarding elements $\mathrm{N}$ and $\mathrm{O}$ since their results for all the studied samples by Morelli $^{\circledR}$ and Conexao ${ }^{\circledR}$ were zero (Table 1).

\section{Discussion}

Translational research is an important component of orthodontic research since it can translate information from the laboratory to enhance the outcomes of patients' treatments ${ }^{3}$. The present research analyzed mini-implants using SEM and EDX to verify their chemical composition and surface design, two aspects of major relevance when choosing the device to be used in a patient.

Titanium is a biocompatible metal with proper mechanical $^{9}$ and corrosion resistance ${ }^{10}$, which makes its presence in the composition of mini-screws very important.

Mini-implants present a composition commercially known as Ti-6al-4v with $\mathrm{Al}$ and $\mathrm{V}$ in addition to Ti. This type of alloy provides the mini-implant with greater resistance if compared with conventional implants with larger diameter. In contrast, such formulation generates lower biological compatibility decreasing the osseointegration phenomenon ${ }^{5}$.

All the analyzed brands presented $\mathrm{Ti}$ as main component, and lower amounts of $\mathrm{Al}$ and $\mathrm{V}$ (score1). Conexao ${ }^{\circledR}$ and Morelli ${ }^{\circledR}$ mini-implants presented $\mathrm{Ti}$ with quantities equivalent to the respective manufacturers' commercial descriptions. Mini-implant SIN ${ }^{\circledR}$ presented lower Ti concentration with statistically significant difference in relation to Morelli ${ }^{\circledR}$ $(\mathrm{p}<0.0001)$ but no significance in relation to Conexao ${ }^{\circledR}$.

Alsamak et al. ${ }^{5}$ identified foreigner mini-implants brands with the presence of $\mathrm{Ti}, \mathrm{V}, \mathrm{Al}$ and $\mathrm{O}$ in quantities similar to the ones found in our research, which corroborates the composition of the Ti 5 grade alloy.

Park et al. ${ }^{11}$ stated that the osseointegration phenomenon does not occur despite the presence of $\mathrm{Ti}$ in mini-implants, which is a very important characteristic to facilitate their removal.

$\mathrm{SIN}^{\circledR}$ presented other components, as $\mathrm{N}(1.59 \%)$, and $\mathrm{O}$ $(18.04 \%)$. Chin et al. ${ }^{12}$ studied 5 different mini-implants associating their XPS survey spectra with a constitution of primarily $\mathrm{C}, \mathrm{O}$ and $\mathrm{Ti}$, but also detecting traces of $\mathrm{N}, \mathrm{Ca}, \mathrm{Fe}$, $\mathrm{Cr}, \mathrm{Cu}, \mathrm{Pb}, \mathrm{Zn}$, and $\mathrm{Si}$. The authors reported it as an apparent problem of surface contamination. Silverstein et al. ${ }^{13}$ evaluated three different brands of mini-implants by XPS and observed that the elements found in all them were mainly $\mathrm{C}$, O, and Ti. They also found were other metals in small amounts, and other trace elements. All three mini-screws showed very different characteristics in surface composition.

Jofré et al. ${ }^{14}$ evaluated the 2-year survival rate of miniimplants that came into contact with stainless steel prior to insertion. SEM and EDX analyses revealed $\mathrm{C}$ and $\mathrm{O}$ in all mini-implants. Those that had contact with stainless steel, additional elements were identified, including $\mathrm{Si}, \mathrm{Ca}, \mathrm{Fe}$, and $\mathrm{Cr}$. The authors found that during the 2-year follow-up, 


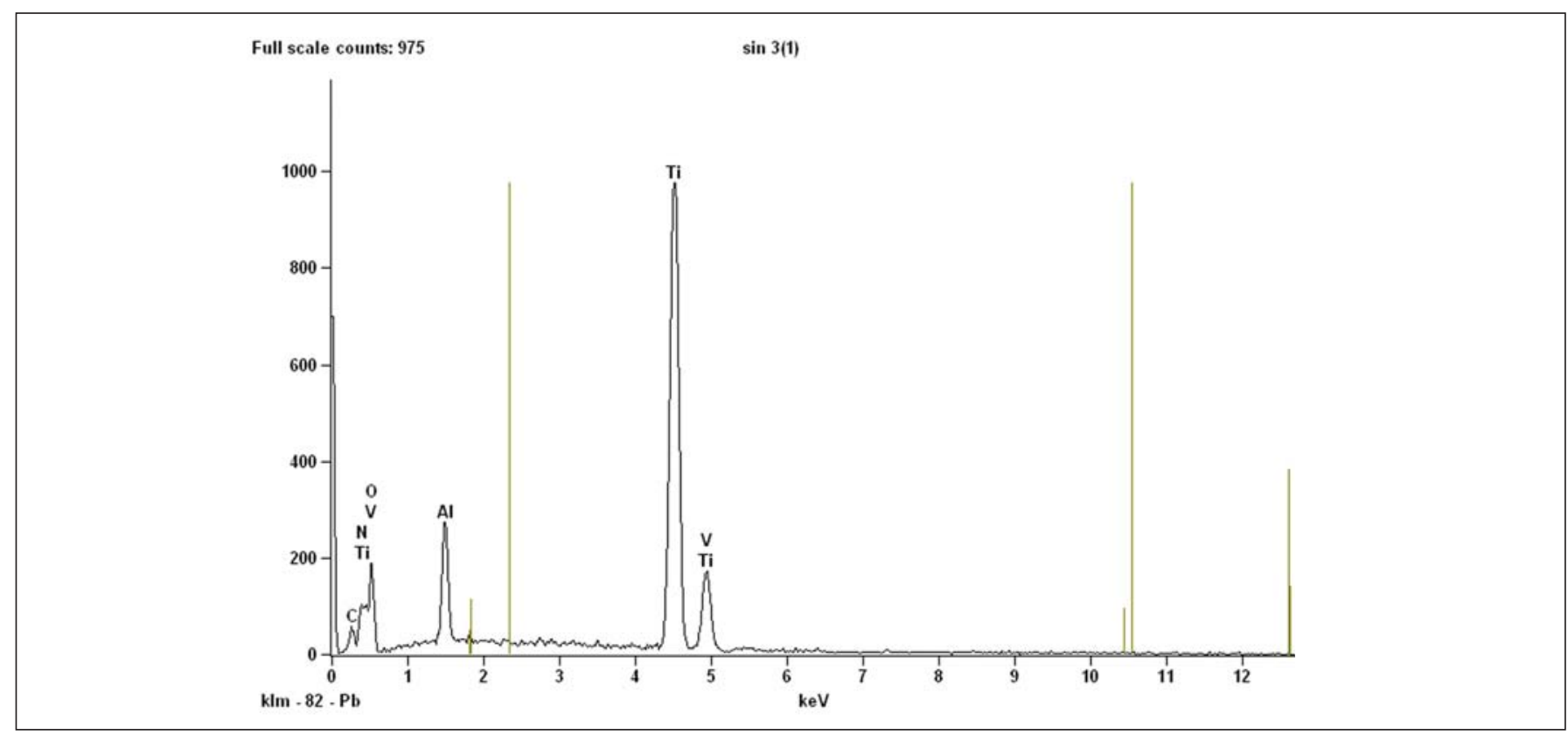

Fig. 6. Graphic of the chemical composition of a SIN ${ }^{\circledR}$ mini-implant showing Ti, Al, V, C, O and N amounts.

Table 1. Chemical elements detected in each group $(n=12)$ of mini-implants $\mathrm{SIN} \AA$, Morelli $\AA$ and Conexao®

\begin{tabular}{ccccc}
\hline Element & \multicolumn{1}{c}{$\begin{array}{c}\text { SIN }^{\circledR} \\
\text { \% mean (S.D.) }\end{array}$} & $\begin{array}{c}\text { Morelli }^{\circledR} \\
\text { \% mean (S.D.) }\end{array}$ & $\begin{array}{c}\text { Conexao }^{\circledR} \\
\text { \% mean (S.D.) }\end{array}$ & $\begin{array}{c}\text { p value } \\
\text { (ANOVA and Tukey's test) }\end{array}$ \\
C & $2.33(0.61)$ & $2.32(0.73)$ & $2.40(0.41)$ & 0.9252 \\
N & $1.59(0.77)$ & $0.00(0.00)$ & $0.00(0.00)$ & - \\
O & $18.04(2.96)$ & $0.00(0.00)$ & $0.00(0.00)$ & - \\
$\mathrm{Al}$ & $4.61(0.17)^{\mathrm{A}}$ & $5.75(0.18)^{\mathrm{B}}$ & $5.32(0.72)^{\mathrm{B}}$ & $<0.0001$ \\
$\mathrm{Ti}$ & $72.88(5.21)^{\mathrm{A}}$ & $88.11(0.64)^{\mathrm{B}}$ & $77.98(8.70)^{\mathrm{A}}$ & $<0.0001$ \\
$\mathrm{~V}$ & $3.15(0.35)^{\mathrm{A}}$ & $4.16(0.23)^{\mathrm{B}}$ & $4.01(0.23)^{\mathrm{B}}$ & $<0.0001$ \\
\hline
\end{tabular}

Results were calculated as percentage and are presented in the table mean and standard deviation. Different letters in rows mean statistically significant difference among the mini-implants $(p<0.05)$

one mini-implant failed (97.8\% survival rate). So, the authors concluded that stainless steel surgical guides does not seem to generate contamination that compromises the survival of mini-implants.

According to Vezeau et al. ${ }^{15}$, the contamination appeared to occur during the manufacturing, packaging and handling processes, as well as to result from sterilization procedures involving undesirable located water condensation, and the heterogeneity of a mixed sterilizer load in an institutional setting. Morra et al. ${ }^{16}$ affirm that airborne $\mathrm{N}$ contaminations in the implants are unavoidable and usual to a reasonable level of inadequate surface treatment and implant handling (during packaging, for example). This type of surface pollution is typically inhomogeneous surrounding the implant, and should not be mistaken with controlled chemical or biochemical modifications.

Generally, as-received mini-implants can present high amounts of $\mathrm{C}$, indicating high level of particulate contamination on oxide surfaces ${ }^{12}$. The present study revealed all the groups with small quantity of $\mathrm{C}$ with non-statistically significant difference among the tested brands.

The success of orthodontic mini-plants depends on the metallurgy applied in their production, which is especially associated with a great quality alloy surcharge and its proper handling. During the process of alloy turning to produce the mini-implants, metallurgical contamination must be prevented $^{17}$. Further studies should investigate whether the contamination of mini-implants surfaces interferes in their biocompatibility or in the stability of their clinical use. A systematic review by Schatzle ${ }^{18}$ presented 363 or $15.3 \%$ failures out of 2374 mini-screws inserted in 1196 patients. The contamination of the mini-implant surface is a possible cause of clinical failure.

The topography analysis revealed that the three brands presented some type of structural defect such as protrusion or striated surfaces, especially in the body, in addition to some roughness. In this study, it was given a score to quantify the surface topography homogeneity. All brands presented score 1, with no statistical difference among them. It is not certain how decisive the interference of such structural alterations are to the success of the mini-implant; although Burmann et al. ${ }^{19}$ states that differences in mini-implant design and the presence of surface irregularities may influence the effectiveness of orthodontic anchorage. 
According to Melsen ${ }^{20}$ the head of mini-implants should be well polished to avoid the accumulation of biofilm on local tissues. This characteristic also decreases the possibility of causing injuries to the surrounding mucous membrane consequently increasing the possibility of success during the treatment. All the studied brands presented favorable characteristics in the area enabling their clinical use.

Further studies should be carried out in order to assess those mini-implants in vivo, which could enable their clinical use with improved safety.

In conclusion, the mini-implants by $\mathrm{SIN}^{\circledR}$, Morelli ${ }^{\circledR}$ and Conexao ${ }^{\circledR}$ presented $\mathrm{Ti}$ as main component of the alloy; the remaining components, such as $\mathrm{Al}$ and $\mathrm{V}$, were also observed in all the analyzed brands. SIN ${ }^{\circledR}$ was the only brand presenting mini-implant with chemical elements $\mathrm{O}$ and N. All miniimplants presented structural defects in the SEM analysis, with no differences among the groups.

\section{Acknowledgements}

We would like to thank the Osvaldo Cruz Foundation (Fiocruz), especially the Electron Microscopy Service, for supporting our research and providing a scanning electron microscope.

\section{References}

1. Prabhu J, Cousley RR. Current products and practice: bone anchorage devices in orthodontics. J Orthod. 2006; 33: 288-307.

2. Kalarickal B. Group distal movement of teeth using micro-screw-implant anchorage-a case report. J Clin Diagn Res. 2014; 8: 26-9.

3. Rossouw E. Translational mini-screw implant research. J Orthod. 2014; 41: s8-s14.

4. Galli C, Piemontese M, Ravanetti F, Lumetti S, Passeri G, Gandolfini M, et al. Effect of surface treatment on cell responses to grades 4 and 5 titanium for orthodontic mini-implants. Am J Orthod Dentofacial Orthop. 2012; 141: 705-14.

5. Alsamak S, Psomiadis S, Gkantidis N. Positional guidelines for orthodontic mini-implant placement in the anterior alveolar region: a systematic review. Int J Oral Maxillofac Implants. 2013; 28: 470-9.

6. Mizrahi E, Mizrahi B. Mini-screw implants (temporary anchorage devices): orthodontic and pre-prosthetic applications. J Orthod. 2007; 34: 80-94.

7. Katiæ V, Kamenar E, Blaževiæ D, Spalj S. Geometrical design characteristics of orthodontic mini-implants predicting maximum insertion torque. Korean J Orthod. 2014; 44: 177-83.

8. Walter A, Winsauer H, Marcé-Nogué J, Mojal S, Puigdollers A. Design characteristics, primary stability and risk of fracture of orthodontic miniimplants: pilot scan electron microscope and mechanical studies. Med Oral Patol Oral Cir Bucal. 2013; 18: e804-10.

9. Gonçalves JP, Shaikh AQ, Reitzig M, Kovalenko DA, Michael J, Beutner $\mathrm{R}$, et al. Detonation nanodiamonds biofunctionalization and immobilization to titanium alloy surfaces as first steps towards medical application. Beilstein J Org Chem. 2014; 26: 2765-73.

10. Carlsson L, Rostlund T, Albretsson B, Albretsson T, Branemark PI. Osseointegration of titanium implants. Acta Orthop Scand. 1986; 57: 385-9.

11. Park HS, Kwon TG, Sung JH. Nonextraction treatment with microscrew implants. Angle Orthod. 2004; 74: 539-49.
12. Chin MYH, Sandham A, de Vries J, Van der Mei HC, Busscher HJ. Biofilm formation on surface characterized micro-implants for skeletal anchorage in orthodontics. Biomaterials. 2007; 28: 2032-40.

13. Silverstein J, Barreto O, França R. Miniscrews for orthodontic anchorage: nanoscale chemical surface analyses. Eur J Orthod. 2015; 13. pii: cjv007.

14. Jofré J, Conrady Y, Carrasco C. Survival of splinted mini-implants after contamination with stainless steel. Int J Oral Maxillofac Implants. 2010; 25: 351-6.

15. Vezeau PJ, Koorbusch GF, Draughn RA, Keller JC. Effects of multiple sterilization on surface characteristics and in vitro biologic responses to titanium. J Oral Maxillofac Surg 1996; 54: 738-46.

16. Morra M, Cassinelli C, Bruzzone G, Carpi A, Di Santi G, Giardino R, et al. Surface chemistry effects of topographic modification of titanium dental implant surfaces: 1. Surface analysis. Int J Oral Maxillofac Implants. 2003; 18: 40-5.

17. Carano A, Velo S, Leone P, Siciliani G. Clinical applications of the miniscrew anchorage system. J Clin Orthod. 2005; 39: 9-24.

18. Schätzle $M$, Männchen $R$, Zwahlen M, Lang NP. Survival and failure rates of orthodontic temporary anchorage devices: a systematic review. Clin Oral Implants Res. 2009; 20: 1351-9.

19. Burmann PF, Ruschel HC, Vargas IA, de Verney JC, Kramer PF. Titanium alloy orthodontic mini-implants: scanning electron microscopic and metallographic analyses. Acta Odontol Latinoam. 2015; 28: 42-7.

20. Melsen B. Mini-implants, where are we? J Clin Orthod. 2005; 39: 539-47. 